\title{
ANALISIS STRATEGI PENGEMBANGAN AGROINDUSTRI KOPI LUWAK DI KABUPATEN TANJUNG JABUNG BARAT
}

\author{
Novia Anjani ${ }^{1)}$, Adlaida Malik ${ }^{2)}$ dan Yanuar Fitri ${ }^{2)}$ \\ 1) Alumni Program Studi Agribisnis Fakultas Pertanian Universitas Jambi \\ 2) Staf Pengajar Program Studi Agribisis Fakultas Pertanian Universitas Jambi \\ Email : noviaanjani1593@yahoo.co.id
}

\begin{abstract}
ABSTRAK
Kopi luwak merupakan salah satu produk olahan Kabupaten Tanjung Jabung Barat yang memanfaatkan kopi kotoran luwak sebagai bahan baku. Nilai tambah yang cukup tinggi dan terjaminnya ketersediaan bahan baku menjadi prospek yang baik dalam pengembangan usaha. Penelitian ini bertujuan untuk menganalisis strategi pengembangan agroindustri kopi luwak di Kabupaten Tanjung Jabung Barat. Penelitian ini dilaksanakan pada tanggal 27 November hingga 23 Desember 2015. Data yang diambil dalam penelitian adalah data selama 6 bulan pada periode Juni - November 2015. Penentuan responden dilakukan secara sengaja (purposive) yang terdiri dari pihak internal dan eksternal dengan pertimbangan bahwa responden memiliki kaitan dan memahami perkembangan usaha agroindustri kopi luwak di Kabupaten Tanjung Jabung Barat. Responden internal yaitu pemilik atau pimpinan agroindustri (3 orang), responden eksternal berasal dari dinas-dinas dan instansi terkait (4 orang). Penelitian ini merupakan penelitian deskriptif analitik dengan pendekatan analisis SWOT. Hasil analisis data lingkungan agroindustri melalui matriks IFAS dan EFAS menunjukkan bahwa pada matriks strategis internal, total nilai kekuatan lebih besar dibandingkan dengan total nilai kelemahan. Pada matriks strategis eksternal, total nilai peluang lebih besar dibandingkan dengan total nilai ancaman, sehingga usaha agroindustri kopi luwak di Kabupaten Tanjung Jabung Barat berada pada posisi Aggressive Strategy. Berdasarkan analisis melalui matriks SWOT, dengan memanfaatkan kekuatan dan peluang maka alternatif strategi yang dapat diterapkan oleh usaha agroindustri kopi luwak yaitu: 1) peningkatan jumlah produksi, 2) diversifikasi dan modifikasi kemasan, 3) perluasan jangkauan pemasaran dan 4) bekerjasama dan menanggapi respon pemerintah.
\end{abstract}

Kata Kunci: Strategi Pengembangan, Kopi Luwak dan Analisis SWOT.

\begin{abstract}
Luwak coffe is one of product in Tanjung Jabung Barat Regency which use coffee from luwak feces as raw material. The quite high add value and availability of raw material becomes a good prospect in business development. This study aims to analyse agroindustry development strategy of luwak coffe in Tanjung Jabung Barat Regency. This study was conducted on November $27^{\text {th }}$ to December $23^{\text {th }} 2015$. Data taken from this study was data for 6 months on June-November 2015. Determining respondents is done intentionally (purposive) which include internal and external parties with some considerations that respondents should concern and understand about luwak coffee agroindustry in Tanjung Jabung Barat Regency. Internal respondent is owner or chief of agroindustry (3 respondents), external respondent come from related departments and instances (4 respondents). This study is descriptive analytic study with SWOT analysis approach. Data analysis result of agroindustry environment through IFAS and EFAS matrix shows that in internal strategic matrix, total value of strengths are higher than total value of weaknesses. In external strategic matrix, total value of opportunities are higher than total value of threats, so that bussines of Luwak coffe agroindustry in Tanjung Jabung Barat Regency is in agressive strategy. Based on analysis through SWOT matrix, by using streghts and opportunities so alternative strategies that can be applied by luwak coffe agroindustry i.e. 1) increasing production, 2) diversification and modification packaging, 3) range market share expansion and 4) cooperate and respond to government's response in developing Luwak coffee industry.
\end{abstract}

Key words: Development Strategy, Luwak coffee and SWOT Analysis. 


\section{PENDAHULUAN}

Salah satu produk unggulan yang dihasilkan oleh Kabupaten Tanjung Jabung Barat dengan produksi yang cenderung meningkat setiap tahunnya adalah komoditi kopi. Kopi yang dibudidayakan di Kabupaten Tanjung Jabung Barat merupakan kopi khas daerah dengan varietas unggulan lokal yang telah memiliki perlindungan hak indikasi - geografis pada tanggal 23 juli 2015 dengan nomor pendaftar id G 000000032 yang diberi nama Liberika Tungkal Jambi atau yang lebih dikenal dengan Liberika Tungkal Komposit (LIBTUKOM). Kopi ini memiliki beberapa keunggulan diantaranya mampu ditanam didataran rendah, buah lebat dan besar, mampu berbuah sepanjang tahun dan tahan terhadap serangan hama. Tingginya produksi kopi namun tidak diimbangi dengan jumlah buruh petik menyebabkan banyak biji kopi matang dimakan oleh hama luwak yang berasal dari hutan semak yang bersebelahan langsung dengan perkebunan kopi. Untuk menanggulangi keadaan, maka dilakukan pengembangan dan peningkatan sistem agribisnis yang berbasis ekonomi kerakyatan dengan upaya pengembangan agroindustri. Strategi yang dilaksanakan yaitu dengan melakukan pengolahan kopi agar menciptakan nilai tambah. Salah satu kegiatan pengolahan kopi yang dilakukan yaitu pengolahan kopi luwak bubuk dengan memanfaatkan biji kopi kotoran luwak sebagai bahan baku utama dalam pengolahan. Kopi yang dimakan luwak terproses bersama enzim pencernaan dan mengalami fermentasi di dalam perut luwak sehingga menciptakan rasa yang unik dan khas (Aris, 2011).

Kabupaten Tanjung Jabung Barat memiliki potensi yang besar dalam pengembangan agroindustri kopi luwak. Terjaminnya ketersediaan bahan baku dengan produk unggulan khas lokal menjadi potensi untuk pengembangan agroindustri kopi luwak. Disamping itu, nilai tambah yang dihasilkan oleh produk kopi luwak bubuk cukup tinggi. Besarnya nilai tambah menunjukkan bahwa kegiatan pengolahan kopi luwak bubuk di Kabupaten Tanjung Jabung Barat sangat menguntungkan sehingga memiliki prospek yang baik untuk dikembangkan (Siregar 2014). Sebagai minuman penyegar yang memiliki banyak manfaat, kopi saat ini juga memiliki eksistensi yang cukup tinggi. Permintaan kopi semakin tinggi dari tahun ke tahun sehingga menjadi peluang bagi usaha, berdasarkan catatan Asosiasi Eksportir dan Industri Kopi Indonesia bahwa rata-rata masyarakat Indonesia kini mengkonsumsi kopi sebanyak 1,6 - 1,7 kg/kapita/tahun (Clara, 2016). Namun, pengembangan agroindustri kopi luwak masih dihadapan pada beberapa kendala seperti lemahnya permodalan sehingga sulit dalam perolehan peralatan dengan teknologi yang lebih modern dan tepat guna. Terbatasnya teknologi ini berefek pula pada terbatasnya volume produksi. Hal ini menyebabkan keuntungan yang diperoleh belum optimal. Untuk itu, perlu dilakukan pengembangan usaha.

Dalam proses pengembangan sebuah usaha, perlu diperhatikan lingkungan internal dan eksternalnya. Suatu agroindustri akan tetap bertahan jika pengusaha mampu mengidentifikasi potensi dan kelemahan yang ada. Dengan mengetahui potensi kelemahan, maka dapat membantu pengusaha untuk menyusun alternatif strategi yang tepat yang dapat diterapkan dalam pengembangan agroindustri. Untuk itu, dibutuhkan suatu analisis strategi untuk mempertahankan kekuatan dan peluang serta mengatasi kelemahan dan ancaman dalam pengembangan agroindustri ini.

Berdasarkan uraian di atas, maka tujuan dalam penelitian ini adalah (1) Mengidentifikasi kekuatan, kelemahan, peluang dan ancaman dalam pengembangan usaha agroindustri kopi luwak di Kabupaten Tanjung Jabung Barat, (2) Menentukan posisi agroindustri kopi luwak di Kabupaten Tanjung Jabung Barat, Dan (3) Merumuskan alternatif strategi pengembangan yang dapat diterapkan dalam pengembangan usaha agroindustri kopi luwak di Kabupaten Tanjung Jabung Barat.

\section{METODE PENELITIAN}

Penelitian ini dilakukan di Kabupaten Tanjung Jabung Barat Provinsi Jambi dengan pertimbangan bahwa lokasi penelitian merupakan daerah yang mengolah kopi luwak bubuk dengan bahan baku biji kopi luwak yang berasal dari biji kopi khas daerah (kopi LIBTUKOM). Objek dalam penelitian ini adalah seluruh agroindustri yang mengolah kopi luwak bubuk di Kabupaten Tanjung Jabung Barat. Data yang digunakan adalah data primer dan data sekunder. Data primer diperoleh langsung dari observasi kelapangan dan wawancara, sedangkan data sekunder berasal dari instansi- 
instansi terkait, studi kepustakaan, internet, laporan-laporan dan hasil-hasil penelitian yang terkait dengan penelitian ini. Adapun pelaksanaan penelitian ini berlangsung dari tanggal 27 November 2015 sampai tanggal 23 Desember 2015. Rentang waktu data yag digunakan adalah periode Juni November 2015.

Penentuan sampel dilakukan melalui metode sensus dimana semua anggota populasi digunakan sebagai sampel (Sugiono, 2010). Dalam penelitian ini yang dijadikan sampel adalah seluruh agroindustri kopi luwak yang ada di daerah penelitian. Adapun jumlah agroindustri yang terdapat di Kabupaten Tanjung Jabung Barat yaitu sebanyak 3 unit usaha (Dinas Perindustrian, Perdagangan dan Promosi Daerah, 2015). Penentuan sampel responden dilakukan secara sengaja (purposive) dengan mempertimbangkan responden yang memiliki kaitan dengan agroindustri kopi luwak di Kabupaten Tanjung Jabung Barat, ahli dibidangnya dan memahami perkembangan usaha agroindustri kopi luwak. Dalam hal ini responden terdiri dari responden internal dan eksternal. Responden pihak internal yakni pemilik atau pimpinan agroindustri dengan pertimbangan bahwa pemimpin bertanggung jawab penuh dan mengetahui keadaan usaha sehingga diharapkan bisa diperoleh hasil yang cukup akurat. Responden pihak eksternal yakni Kepala Bidang Usaha Mikro, Kecil dan Menengah Kabupaten Tanjung Jabung Barat, Kepala Seksi Kerja Sama dan Pelayanan Pengkajian Teknologi Pertanian Provinsi Jambi, Kepala Bidang Perindustrian dan promosi Daerah Kebupaten Tanjung Jabung Barat, dan Dosen fakultas teknologi pertanian sekaligus salah satu peneliti dari Lembaga Penelitian Universitas Jambi. Pemilihan responden ini dilakukan dengan pertimbangan bahwa usaha kopi luwak merupakan usaha agroindustri yang berada dibawah pengawasan dan/atau pelatihan pihak-pihak tersebut. Penilaian pembobotan dan peratingan diperoleh dengan cara diskusi dan kuisioner.

Analisis data dalam penelitian ini adalah analisis deskriptif dengan pendekatan analisis SWOT. Analisis SWOT adalah teknik relatif untuk memformulasikan strategi dan kebijakan (Muhammad, 2012). Analisis SWOT dilakukan dalam tiga tahapan: pertama, mengidentifikasi lingkungan internal (kekuatan dan kelemahan) dan lingkungan eksternal (peluang dan ancaman) agroindustri kopi luwak. Langkah awal identifikasi yaitu dengan melakukan evaluasi kondisi agroindustri (lingkungan internal dan lingkungan eksternal) kelapangan. Penelusuran kondisi lingkungan secara sistematis dan fluktual dilakukan dengan wawancara menggunakan kuisioner penelitian kepada pemilik usaha. Kedua, faktorfaktor kekuatan, kelemahan, peluang dan ancaman diformulasikan kedalam sebuah model matriks yang dikenal dengan matrik IFAS yang berisi kondisi internal agroindustri (kekuatan dan kelemahan) dan matriks EFAS yang berisi kondisi eksternal agroindustri (peluang dan ancaman). Setelah faktorfaktor dirumuskan dalam matriks IFAS dan EFAS, langkah selanjutnya adalah memberikan bobot dan rating pada masing-masing faktor. Penentuan bobot dilakukan dengan jalan yang mengajukan identifikasi faktor strategis internal dan eksternal. Metode yang digunakan ialah metode Paired Comparison yaitu alat untuk menentukan skala prioritas dari beberapa pilihan (Kinnear and Tailor, 1991 dalam Yanti, 2006). Untuk menentukan bobot setiap variabel digunakan skala 1, 2 dan 3. Skala yang digunakan untuk pengisian kolom adalah:

$1=$ jika indikator horizontal kurang penting dari indikator vertikal.

$2=$ jika indikator horizontal sama penting dari indikator vertikal.

$3=$ jika indikator horizontal lebih penting dari indikator vertikal.

Tabel 1. Penilaian Bobot Strategis Internal Agroindustri

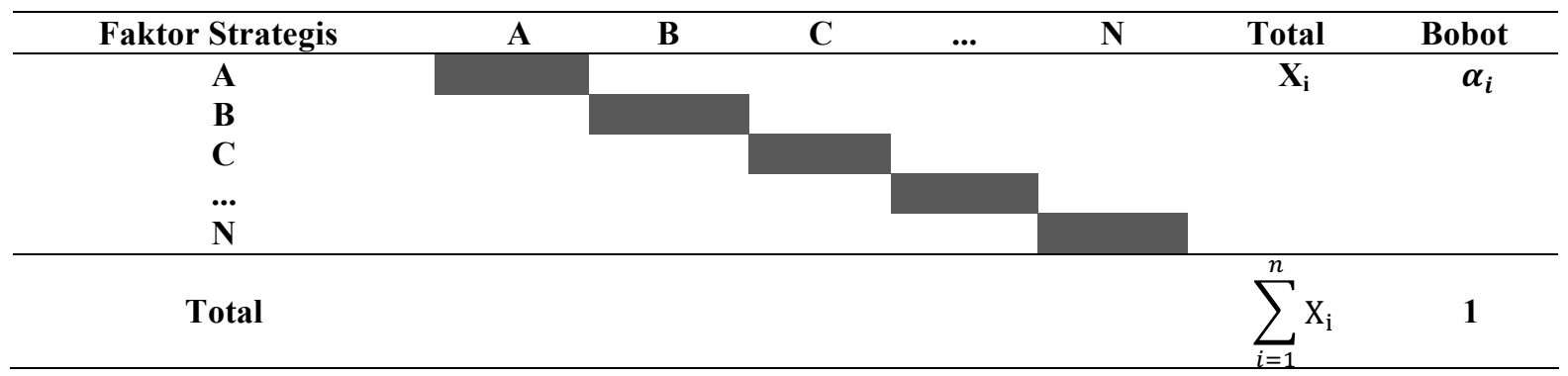

Sumber: Kinnear and Tailor, 1991 dalam Yanti, 2006 
Bobot setiap variabel diperoleh dengan menentukan nilai setiap variabel terhadap jumlah nilai keseluruhan variabel dengan menggunakan rumus (Kinnear and Tailor, 1991 dalam Yanti, 2006).

$$
\alpha_{i}=\frac{\mathrm{Xi}}{\sum_{\mathrm{i}=1}^{\mathrm{n}} \mathrm{X}_{\mathrm{i}}}
$$

Keterangan :

$\alpha \mathrm{i}=$ bobot variabel ke-i

$\mathrm{Xi}=$ nilai variabel ke- $\mathrm{i}$

$\mathrm{i}=1,2,3, \ldots ., \mathrm{n}$

$\mathrm{n}=$ jumlah variabel

Setelah pemberian bobot dan rating, setiap bobot dan rating dikalikan untuk menghasilkan skor terbobot dan menjumlahkan masing-masing faktor kemudian mencari selisih dari penjumlahan faktor internal (kekuatan dan kelemahan) dan selisih dari penjumlahan faktor eksternal (peluang dan ancaman) untuk memperoleh nilai titik kuadran yang digunakan untuk menentukan keberadaan posisi agroindustri yang ditunjukkan oleh diagram analisis SWOT. Ketiga, setelah posisi diperoleh maka diketahui strategi yang harus diterapkan dalam agroindustri. Setelah mengetahui strategi apa yang harus diterapkan maka langkah selanjutnya yaitu memformulasikan kondisi lingkungan kedalam matriks SWOT untuk mencari alternatif strategi apa saja yang dapat diterapkan pada agroindustri agar dapat berkembang.

\section{HASIL DAN PEMBAHASAN}

Agroindustri kopi luwak merupakan industri pengolahan kopi luwak bubuk yang memanfaatkan biji kopi kotoran luwak sebagai bahan baku utama. Berdasarkan data dari Dinas Perindustrian, Perdagangan dan Promosi Daerah Kabupaten Tanjung Jabung Barat terdapat 3 (tiga) agroindustri kopi luwak, diantaranya: Buana Putra, Mak Denok dan Sri Utomo. Berdasarkan hasil penelitian Siregar (2014) bahwa kegiatan pengolahan biji kopi luwak green beans menjadi kopi luwak bubuk di Kabupaten Tanjung Jabung Barat sangat menguntungkan dan memberikan nilai tambah yang relatif tinggi. Dari penelitian ini dapat diambil kesimpulan bahwa usaha ini memiliki prospek yang cukup baik untuk dikembangkan. Untuk itu, diperlukan strategi pengembangan dengan membandingkan faktor lingkungan internal den faktor lingkungan eksternal yang ada dengan menggunakan analisis SWOT. Berikut adalah identifikasi lingkungan internal dan eksternal agroindustri kopi luwak di Kabupaten Tanjung Jabung Barat berdasarkan hasil penelitian.

\section{Identifikasi Faktor Lingkungan Internal dan Lingkungan Eksternal}

Menurut Muhammad (2012), dalam pelaksanaan agroindustri atau suatu usaha terdapat beberapa elemen yang ada dalam lingkungan yang memberikan pengaruh baik secara langsung maupun tidak langsung pada perusahaan. Adapun elemen yang mempengaruhi usaha adalah elemen : 1) lingkungan ekonomi, berkaitan dengan bagaimana usaha memproduksi, 2) lingkungan teknologi, berkaitan dengan teknologi yang digunakan dan perkembangan keilmuan baru, 3) lingkungan persaingan, 4) lingkungan hukum, 5) lingkungan politik, berkaitan dengan pembuatan perencanaan untuk bermitra dan urusan administrasi serta kebijakan daerah, 6) lingkungan sosial, 7) lingkungan pelanggan dan, 8) lingkungan geofisik.

Kegiatan agroindustri merupakan kegiatan bisnis, dimana dalam aktivitasnya ditujukan untuk mencari keuntungan. Kondisi lingkungan akan mempengaruhi aktivitas yang dijalankan dalam bisnis. Menurut Abdul dan Darsono (2015), lingkungan dalam terdiri dari: 1) material, 2) tenaga kerja, 3) alat kerja, 4) metode kerja, 5) modal kerja, 6) informasi, dan 7) kepemimpinan, merupakan faktor-faktor yang menentukan keberhasilan bisnis dalam mencari laba. Sedangkan lingkungan luar terdiri dari: 1) ilmu pengetahuan, 2) teknologi, 3) ekonomi, 4) politik, 5) sosial-budaya, dan 6) persaingan, merupakan faktor-faktor yang mempengaruhi keberhasilan bisnis. 
Faktor-faktor lingkungan internal pada agroindustri kopi luwak di Kabupaten Tanjung Jabung Barat ditinjau dari beberapa aspek seperti: modal, lokasi usaha, teknologi, sumberdaya manusia (tenaga kerja) dan manajemen. Sehingga dari faktor-faktor tersebut diperoleh faktor strategis kekuatan dan faktor strategis kelemahan. Faktor-faktor lingkungan eksternal pada agroindustri kopi luwak di Kabupaten Tanjung Jabung Barat ditinjau dari beberapa aspek seperti: pesaing, konsumen, permintaan, bahan baku dan kebijakan pemerintah. Dari faktor-faktor eksternal diperoleh faktor strategis peluang dan faktor strategis ancaman. Berikut hasil identifikasi lingkungan internal dan eksternal

\section{Kekuatan}

a. Modal sendiri

Modal yang digunakan untuk membuka usaha berasal dari pengrajin sendiri. Hal ini menunjukkan bahwa pengrajin tidak perlu terbebani oleh hak kepemilikan, beban biaya bunga/sewa maupun besarnya risiko jika bukan milik sendiri.

b. Lokasi usaha yang strategis

Agroindustri berada pada akses jalan lintas dan dekat dengan pasar memberikan potensi yang baik bagi agroindustri. agroindustri dapat dengan mudah dan lebih cepat dalam penyaluran hasil produk yang didukung prasarana yang baik. Agroindustri berada dekat dengan sumber bahan baku juga berpotensi baik bagi agroindustri, agroindustri dapat dengan mudah memperoleh bahan baku.

c. Teknologi mekanik - manual

Peralatan yang digunakan meskipun terbilang masih sederhana namun sudah cukup berkembang, sudah ada peralatan mesin yang digunakan sehingga proses produksi lebih efektif dan efisien.

d. Aktif dalam promosi

Pengrajin aktif mengikuti pameran produk asli daerah di dalam daerah maupun luar daerah dan membuat akun media sosial untuk publikasi melalui media internet.

e. Produk terdaftar dan memiliki izin usaha.

Produk dengan merk dagang terdaftar, ini berarti agroindustri telah memilki izin usaha, izin dari dinas kesehatan serta memiliki sertifikasi halal. Dengan adanya kekuatan ini dapat menjadi potensi untuk menjaga kepercayaan konsumen.

f. Volume produksi yang meningkat.

Dengan peningkatan produksi berarti peluang bagi agroindustri dalam mendapatkan keuntungan dan melakukan perluasan pasar.

g. Pengendalian mutu bahan baku.

Pengrajin selalu berusaha menjaga kualitas bahan baku dengan meminimalisir kesalahan bahan baku yang masuk, bahan baku yang diolah adalah biji kopi luwak asli tanpa campuran.

\section{Kelemahan}

a. Modal terbatas.

Keterbatasan modal menjadi hambatan bagi usaha dalam mengembangkan agroindustri. Agroindustri terkendala dalam kinerja, perluasan jangkauan pemasaran dan pengadopsian teknologi baru yang lebih canggih untuk peningkatan kualitas produk.

b. Aplikasi inovasi teknologi lemah.

Selain minimnya modal yang dimiliki, sulitnya penerapan inovasi baru dalam teknologi yang dikelola dalam usaha adalah karena kekhawatiran pada kerugian. Hal ini menyebabkan usaha lemah dalam penggunaan teknologi yang lebih canggih.

c. SDM terbatas.

Jumlah tenaga kerja yang sedikit dan pendidikan yang minim menyebabkan lemah dalam pengambilan keputusan terhadap penerapan inovasi-inovasi yang dapat meningkatkan pengembangan usaha. Jumlah produksi yang dihasilkan lebih kecil.

d. Kemasan yang digunakan sederhana.

Ditemukan sebagian kecil kemasan yang hanya menggunakan plastik kaca dan diberi label. Penggunaan kemasan plastik biasa dapat mengurangi kesegaran dan kualitas kopi karena kopi 
akan menghasilkan gas $\mathrm{CO}_{2}$ setelah penyangraian. Kopi sangrai tidak baik bila dibiarkan berinteraksi dengan udara bebas yang mengandung zat asam/oksigen dan cahaya matahari, karena kesegaran kopi akan menurun drastis.

e. Manajemen organisasi yang kurang baik.

Penetapan tugas dan tanggung jawab akan memperlancar kegiatan proses produksi. Namun, terbatasnya sumber daya pengelola dalam agroindustri kopi luwak Kabupaten Tanjung Jabung Barat menyebabkan belum terealisasinya penerapan manajemen organisasi yang tepat yang akan menyebabkan timbulnya hambatan dalam usaha.

\section{Peluang}

a. Volume permintaan meningkat.

Selama periode penelitian (Juni - November 2015) permintaan cenderung mengalami peningkatan. Kondisi ini menjadi peluang agroindustri dalam pengembangan produk.

b. Eksistensi kopi

Saat ini kopi merupakan minuman yang digemari dari berbagai kalangan. Orang-orang lebih banyak memilih kopi untuk bersantai atau pada saat istirahat atau yang lebih dikenal dengan istilah coffe break.

c. Harga bahan baku stabil

Tidak ada peningkatan bahan baku dapat menekan harga biaya produksi untuk bahan penolong lain yang berfluktuatif

d. Bahan baku mudah diperoleh

Dalam sepekan akan ada orang yang mengantarkan bahan baku kepada agroindustri. Semakin luas lahan perkebunan kopi berarti semakin banyak ketersediaan kopi yang dimakan luwak dan semakin banyak pula ketersediaan bahan baku. Selain itu kotoran mudah didapat dengan cara memungut dan mengumpulkan kotoran luwak dari bawah-bawah pohon. Jumlah ketersediaan bahan baku memenuhi kapasitas produksi.

e. Adanya dukungan pemerintah

Dukungan berupa bantuan peralatan, promosi, maupun pelatihan-pelatihan dan sosialisasi yang dapat membantu perkembangan agroindustri.

\section{Ancaman}

a. Terdapat pesaing produk sejenis

Adanya berbagai jenis produk kopi yang beredar yang menjadi pesaing produk kopi luwak. Disamping itu, terdapat agroindustri lain yang mengelola dan menghasilkan produk sejenis dari bahan baku yang berasal dari tempat yang berbeda. Namun dalam perkembangannya pengrajin tidak terlalu khawatir karena setiap usaha-usaha tersebut memiliki segmen pasar masing- masing sehingga tingkat persaingan lokal tidak begitu berpengaruh.

b. Terdapat pesaing produk substitusi

Banyaknya minuman pengganti seperti teh, susu, coklat dan lainnya yang beredar dipasaran.

c. Jumlah konsumen berfluktuasi

Tidak adanya kepastian konsumen yang membeli produk sehingga sulit juga dalam penentuan berapa besar jumlah produksi yang akan dilaksanakan.

d. Biaya kepengalihan produk lain lebih kecil

Kecilnya biaya pengalihan untuk produk pengganti menyebabkan orang yang memiliki pendapatan rendah akan memilih produk kopi hitam biasa yang lebih murah ataupun produk substitusi lain dibanding dengan produk kopi luwak bubuk.

e. Tidak adanya kepastian jumlah bahan baku dalam jumlah besar

Kontinuitas pasokan bahan baku belum bisa dipenuhi mengingat bahan baku yang diperoleh merupakan dari luwak liar. Ketidakpastian pasokan menjadikan sulitnya agroindustri melakukan pemasaran dengan sistem kontrak dalam jumlah besar oleh konsumen luar negeri.

f. Populasi luwak masa mendatang

Terancamnya populasi luwak dimasa mendatang akibat berkurangnya semak karena adanya pembukaan lahan untuk kelapa sawit maupun pengalihan pertanian kopi itu sendiri menjadi lahan 
perkebunan kelapa sawit. Selain itu, ada ancaman berkurangnya ketersediaan bahan baku karena tanaman yang diusahakan saat ini merupakan tanaman tua yang berumur hingga 40 tahun dan jarang melakukan peremajaan sehingga dapat menurunkan produktivitas produk.

g. Ketersediaan air bersih yang tidak menentu

Terbatasnya ketersediaan air untuk pencucian bahan baku, karena air yang digunakan tidak boleh mengandung logam berat sebab akan merusak kualitas kopi.

\section{Penentuan Posisi}

Penentuan posisi dilakukan berdasarkan penilaian selisih dari jumlah total skor terbobot kekuatan dan skor terbobot kelemahan pada matriks IFAS (Internal Factor Analysis Strategic) dan penilaian selisih dari jumlah total skor terbobot peluang dan skor terbobot ancaman pada matriks EFAS (Eksternal Factor Analysis Strategic). Penentuan nilai bobot diperoleh berdasarkan kuisioner yang disebar kepada 3 pengrajin kopi luwak, pihak pemerintah dan lembaga penelitian \& pengembangan dengan menggunakan metode Paired Comparison. Matriks IFAS dan EFAS agroindustri kopi luwak di Kabupaten Tanjung Jabung Barat dapat dilihat pada Tabel 2.

Tabel 2. Matrik IFAS-EFAS agroindustri kopi luwak di Kabupaten Tanjung Jabung Barat

\begin{tabular}{|c|c|c|c|c|}
\hline & $\begin{array}{r}\text { Faktor - faktor Strategi } \\
\end{array}$ & Bobot & Rating & Bobot x Rating \\
\hline \multicolumn{5}{|c|}{ Kekuatan (S) } \\
\hline 1. & Modal sendiri & 0,076 & 2,5 & 0,19 \\
\hline 2. & Lokasi strategis & 0,089 & 3,3 & 0,29 \\
\hline 3. & Teknologi mekanik - manual & 0,079 & 2,3 & 0,18 \\
\hline 4. & Promosi produk & 0,086 & 2,3 & 0,20 \\
\hline 5. & Produk dagang terdaftar dan memiliki izin usaha & 0,080 & 3,8 & 0,30 \\
\hline 6. & Volume produksi meningkat & 0,084 & 2,8 & 0,24 \\
\hline 7. & Bahan baku terkontrol & 0,091 & 3,3 & 0,30 \\
\hline \multicolumn{2}{|r|}{ Total } & & & 1,70 \\
\hline \multicolumn{2}{|r|}{ Kelemahan (W) } & & & \\
\hline 8. & Modal terbatas & 0,060 & 2,0 & 0,12 \\
\hline 9. & Inovasi teknologi lemah & 0,089 & 2,5 & 0,22 \\
\hline 10. & SDM yang digunakan terbatas & 0,085 & 2,8 & 0,24 \\
\hline 11. & Kemasan masih sederhana & 0,094 & 1,8 & 0,17 \\
\hline 12. & Manajemen organisasi kurang baik & 0,087 & 2,5 & 0,22 \\
\hline \multicolumn{2}{|r|}{$\begin{array}{c}\text { Total } \\
\end{array}$} & 1,000 & & $\mathbf{0 , 9 7}$ \\
\hline \multicolumn{2}{|r|}{ Faktor - faktor Strategi } & Bobot & Rating & Bobot $x$ Rating \\
\hline \multicolumn{2}{|r|}{ Peluang (O) } & & & \\
\hline 1. & Volume permintaan meningkat & 0,075 & 3,5 & 0,26 \\
\hline 2. & Eksistensi kopi diberbagai kalangan & 0,086 & 3,3 & 0,28 \\
\hline 3. & Harga bahan baku & 0,073 & 2,8 & 0,20 \\
\hline 4. & Bahan baku mudah diperoleh & 0,084 & 3,3 & 0,28 \\
\hline 5. & Ada kebijakan pemerintah & 0,100 & 3,5 & 0,35 \\
\hline \multicolumn{2}{|r|}{ Total } & & & 1,38 \\
\hline \multicolumn{2}{|r|}{ Ancaman (T) } & & & \\
\hline 6. & Terdapat pesaing sejenis & 0,083 & 3,0 & 0,25 \\
\hline 7. & Terdapat pesaing substitusi & 0,081 & 2,3 & 0,19 \\
\hline 8. & Jumlah konsumen berfluktuasi & 0,079 & 3,0 & 0,24 \\
\hline 9. & Biaya pengalihan keproduk lain kecil & 0,078 & 2,0 & 0,16 \\
\hline 10. & Kepastian kapasitas dalam jumlah besar & 0,082 & 1,5 & 0,12 \\
\hline 11. & Populasi luwak masa mendatang & 0,090 & 2,0 & 0,18 \\
\hline \multirow[t]{2}{*}{12.} & Ketersediaan air bersih tak menentu & 0,089 & 2,5 & 0,22 \\
\hline & $\begin{array}{l}\text { Total } \\
\end{array}$ & $\mathbf{1 , 0 0 0}$ & & $\mathbf{1 , 3 5}$ \\
\hline
\end{tabular}


Penentuan posisi agroindustri kopi luwak di Kabupaten Tanjung Jabung Barat dilakukan dengan mengurangi masing-masing total nilai skor terbobot dari faktor strategis kekuatan dan kelemahan dan pengurangan total nilai skor terbobot dari faktor stretegis peluang dan ancaman. Dari matriks IFAS dapat diketahui total nilai faktor strategis kekuatan adalah 1.70, jika dikurang dengan total nilai faktor strategis kelemahan sebesar 0.97 maka diperoleh titik kuadran pertama yaitu sebesar 0.73 . Total nilai faktor strategis peluang adalah 1.38 dikurangi dengan total nilai faktor strategis ancaman sebesar 1.35 sehingga diperoleh titik kuadran yang kedua yaitu sebesar 0.03 . Melalui hasil selisih total nilai skor terbobot tersebut maka dapat diketahui posisi agroindustri kopi luwak di Kabupaten Tanjung Jabung Barat yang digambarkan dalam diagram analisis SWOT (Gambar 1).

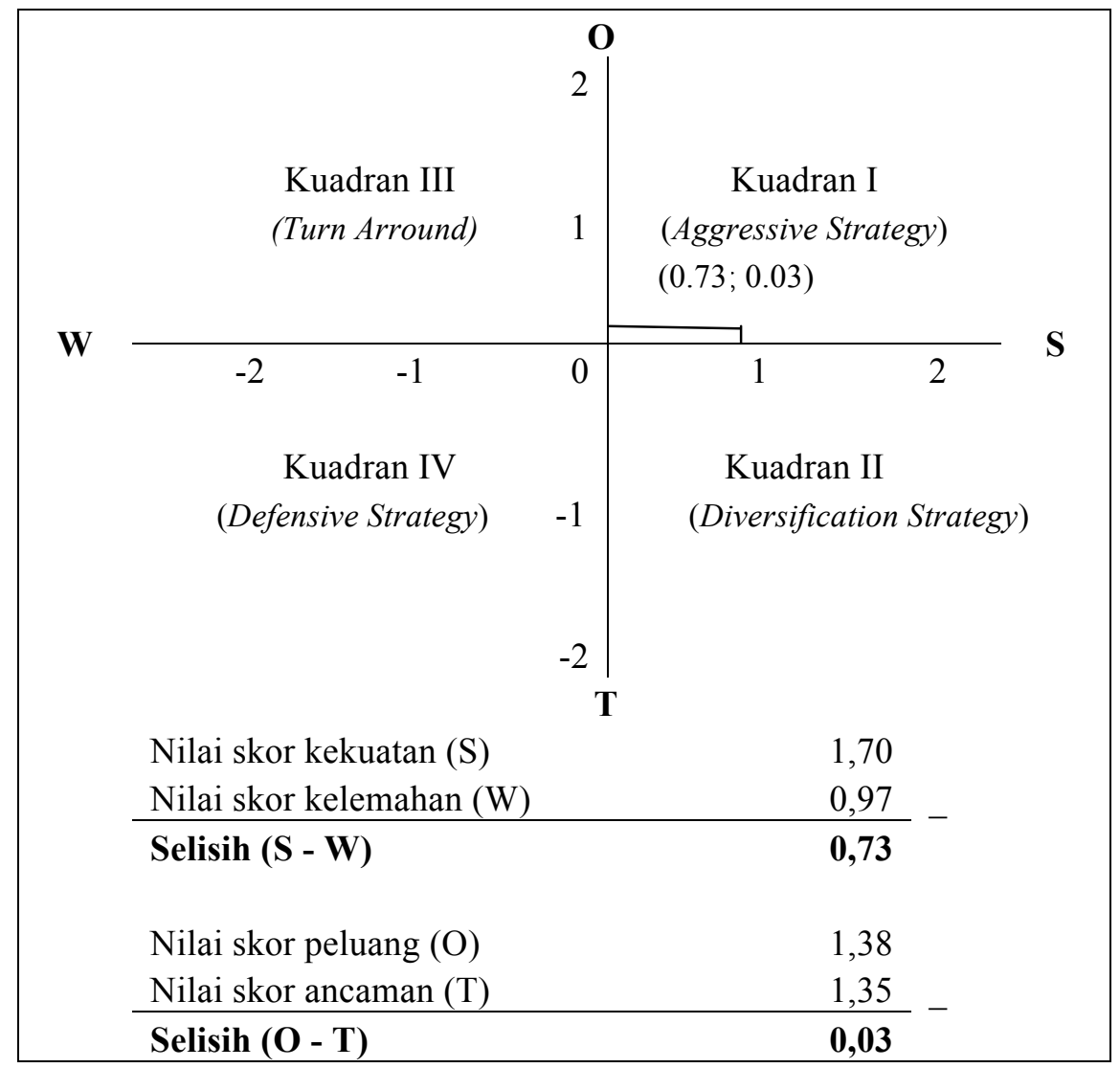

\section{Gambar 1. Diagram Analisis SWOT Agroindustri Kopi Luwak di Kabupaten Tanjung Jabung Barat}

Berdasarkan diagram analisis SWOT pada Gambar 1 diatas dapat dilihat posisi dari agroindustri kopi luwak di Kabupaten Tanjung Jabung Barat terletak pada kuadran 1. Menurut Rangkuti (2014) posisi ini merupakan situasi yang sangat menguntungkan. Agroindustri ini memiliki kekuatan dan peluang yang dapat dimanfaatkan. Adapun strategi yang dapat diterapkan dalam kondisi ini adalah mendukung kebijakan pertumbuhan yang agresif (growth oriented strategy) atau strategi agresif (aggressive strategy). Posisi ini mengusulkan strategi memanfaatkan kekuatan agar peluang yang ada bisa dimanfaatkan (Muhammad, 2012).

\section{Alternatif Strategi Agroindustri Kopi Luwak di Kabupaten Tanjung Jabung Barat}

Identifikasi kondisi lingkungan internal dan eksternal memperlihatkan bahwa dalam aktivitas usaha agroindustri kopi luwak dipengaruhi oleh beberapa faktor lingkungan internal seperti modal, lokasi usaha, teknologi, sumberdaya manusia (tenaga kerja), dan manajemen. Selain itu usaha juga dipengaruhi oleh faktor yang berasal dari luar usaha yang disebut lingkungan eksternal seperti pesaing, 
konsumen, permintaan, bahan baku dan kebijakan pemerintah (dukungan pemerintah). Lingkunganlingkungan tersebut menciptakan potensi dan kendala bagi kelangsungan usaha. Berdasarkan analisis matriks IFAS dan EFAS diketahui posisi agroindustri kopi luwak di Kabupaten Tanjung Jabung Barat berada pada kuadran 1 dengan titik koordinat $(0.73 ; 0.03)$.

Berdasarkan posisi yang dimiliki, maka strategi yang diterapkan dalam pengembangan agroindustri kopi luwak di Kabupaten Tanjung Jabung Barat yaitu strategi agresif. Berdasarkan matriks SWOT (Lampiran 1) maka pilihan strategi yang digunakan yaitu strategi SO dimana dalam strategi ini memanfaatkan kekuatan agar peluang yang ada bisa dimanfaatkan (Rangkuti, 2014). Adapun alternatif strategi yang dapat dimanfaatkan yaitu:

a. Peningkatan jumlah produksi

Tersedianya bahan baku secara kontinu dan jumlah yang memenuhi kapasitas menjadi potensi bagi agroindustri dalam meningkatkan produksi. Besarnya potensi bahan baku dan mudah dalam perolehannya, dapat dimanfaatkan untuk peningkatan kapasitas produksi kopi luwak bubuk. Peningkatan produksi bertujuan dilakukan agar permintaan yang mengalami peningkatan pada setiap bulannya dapat terpenuhi. Selain itu, adanya permintaan khusus pada waktu tertentu serta trend kopi saat ini yang tengah diminati menjadi peluang dalam pengembangan. Eksistensi kopi dikalangan masyarakat mulai dari kalangan remaja hingga orang tua dan popularitasnya yang ditandai dengan mulai membanjirinya cafe-cafe kopi menjadi potensi untuk peningkatan produksi. Daya tarik masyarakat terhadap kopi menjadi peluang besar untuk meningkatkan penjualan produk. Hal ini sejalan dengan penelitian Irene, dkk (2006), bahwa meningkatkan jumlah produksi bertujuan untuk memperbesar skala usaha. Kemudian Resti (2015) menambahkan bahwa dengan pengembangan jumlah produksi dapat menjadi alternatif dalam mengantisipasi volume permintaan.

b. Diversifikasi dan modifikasi kemasan

Tidak adanya pesaing produk yang mengolah bahan baku yang sama berpotensi bahan baku hanya dialokasikan untuk pembuatan kopi luwak bubuk. Mengingat potensi dan nilai tambah dari kopi luwak, memberi peluang besar terhadap pengembangan produk kopi luwak. Salah satu cara meningkatkan pengembangan yaitu dengan melakukan perbaikan maupun inovasi kemasan kopi luwak bubuk dengan berbagai varian ukuran kemasan seperti melakukan penambahan jenis ukuran kemasan dalam bentuk kemasan kopi luwak instan. Perbaikan kemasan juga dapat dilakukan dengan memodifikasi atau memperindah desain kemasan agar lebih menarik konsumen. Selain itu, menciptaan kopi dalam bentuk kemasan instan langsung seduh dengan penambahan gula langsung pada kemasan juga menjadi peluang usaha untuk meningkatkan daya tarik konsumen. Sesuai penelitian Nuning (2011) bahwa upaya diversifikasi menjadi solusi peningkatan agroindustri dengan cara menciptakan inovasi baik pilihan rasa sehingga segmen konsumen menjadi lebih beragam maupun dengan inovasi kemasan.

c. Perluasan jangkauan pangsa pasar

Melakukan perluasan pangsa pasar dengan memanfaatkan lokasi yang strategis yang berjarak \pm $2 \mathrm{~km}$ dari pasar untuk mempermudah distribusi produk. Perluasan jangkauan pemasaran perlu dilakukan untuk meningkatkan dan mencari konsumen baru serta mengenalkan produk pada jangkauan yang lebih luas. Saat ini pemasaran produk agroindustri kopi luwak masih terbatas hanya pada outlet oleh-oleh dan beberapa pasar swalayan yang ada di daerah Tanjung Jabung Barat dan Kota Jambi serta beberapa pelanggan dari luar provinsi. Untuk itu, perluasan pangsa pasar masih sangat diperlukan agar kopi luwak ini dapat dikenal lebih banyak daerah dan menjadi produk andalan Kabupaten Tanjung Jabung Barat. Sejalan dengan penelitian Nuning (2011) perluasan segmen pasar diperlukan untuk pengenalan produk. Selain itu Nuning berpendapat pula bahwa pasar luar negeri dapat menjadi target pasar yang potensial.

Memproduksi kopi luwak dari bahan baku berkualitas menjadi potensi agar produk dapat bersaing dipasaran. Kualitas produk perlu dipertahankan dan ditingkatkan agar kepuasan konsumen tercapai. Pengrajin menjalin hubungan kemitraan yang baik dengan pemasok agar kelangsungan produksi terjaga. Langkah yang dilakukan dalam rangka perluasan pasar adalah dengan aktif dalam memberikan promosi dengan keunggulan produk khas agar mudah dikenal secara meluas. Promosi merupakan kegiatan pengenalan produk kepada masyarakat (konsumen) yang bertujuan untuk 
menambah lokasi pemasaran dan permintaan. Suatu produk betapapun bermanfaatnya jika tidak dikenal oleh konsumen maka produk tersebut tidak akan diketahui manfaatnya dan mungkin tidak akan dibeli oleh konsumen. Promosi produk dapat dilakukan dengan memanfaatkan berbagai media. Sesuai penelitian Fatmawati (2006), promosi dilakukan dengan memanfaatkan beberapa media seperti media elektronik maupun media cetak, misalnya denga cara pengiklanan melalui radio daerah dan koran daerah. Selain itu, promosi produk kopi luwak juga bisa dilakukan dengan membuat papan reklame atau leaflet, membuat akun pribadi kopi luwak pada media sosial mengingat tingginya perkembangan teknologi saat ini perlu dimanfaatkan dan iklan - iklan pada koran daerah. Untuk perluasan pemasaran juga perlu melakukan ekspansi ke beberapa coffe shop yang sering digandrungi masyarakat. Dengan mengantongi izin usaha dan sertifikasi halal diharapkan dapat menjaga kepercayaan konsumen pada produk.

d. Bekerja sama dan menanggapi respon pemerintah

Melakukan kerja sama dengan pihak pemerintah untuk mengembangkan produk dan promosi secara efektif dan meluas dalam rangka perluasan pasar. Menanggapi respon pemerintah untuk mengembangkan usaha dan memanfaatkan bantuan peralatan secara optimal juga perlu dilakukan untuk meningkatkan kualitas produk. Perhatian khusus pemerintah Kabupaten Tanjung Jabung Barat terhadap agroindustri kopi luwak bubuk merupakan peluang yang besar. Pemerintah memberikan bantuan peralatan dan memberikan penyuluhan, diseminasi serta sosialisasi dalam penanganan pasca panen kopi. Pemerintah membantu mencarikan solusi dalam menghadapi kendala-kendala dalam proses pengembangan produk. Selain itu, pemerintah juga membantu dalam pemasaran kopi luwak bubuk dengan melakukan promosi produk daerah yang salah satunya produk kopi luwak serta mengikutsertakan produk dalam pameran produk khas unggulan Kabupaten Tanjung Jabung Barat diberbagai kota/provinsi.

Sejalan dengan penelitian Fatmawati (2006), bermitra dengan pemerintah menjadi peluang bagi pengrajin agroindustri untuk menjual dan mempromosikan produknya karena tempat ini sering dikunjungi oleh tamu- tamu baik dari dalam maupun luar Provinsi Jambi yang datang untuk membeli produk asli daerah.

\section{KESIMPULAN}

Agroindustri kopi luwak bubuk merupakan salah satu usaha mikro yang ada di Kabupaten Tanjung Jabung Barat yang dikembangkan dalam bentuk industri pengolahan skala rumah tangga dengan jumlah tenaga kerja aktif 2 - 4 orang yang berasal dari dalam maupun luar keluarga. Lingkungan internal agroindustri kopi luwak berupa kekuatan meliputi: modal yang digunakan adalah modal sendiri, lokasi yang strategis, peralatan yang digunakan dalam agroindustri merupakan teknologi mekanik - manual, cukup aktif dalam promosi produk, produk dengan merk dagang terdaftar dan memiliki izin usaha, volume produksi meningkat dan manajemen pengendalian mutu yang terkontrol. Lingkungan internal berupa kelemahan meliputi: modal terbatas, inovasi teknologi yang lemah, sumber daya manusia atau tenaga kerja yang digunakan terbatas, adanya kemasan yang masih sederhana dan kurang tepatnya penetapan manajemen organisasi. Lingkungan eksternal berupa peluang meliputi: volume permintaan yang meningkat, eksistesi kopi diberbagai kalangan, harga bahan baku yang stabil dengan perolehan yang mudah dan memenuhi kapasitas produksi dan ada dukungan pemerintah. Lingkungan eksternal berupa ancaman meliputi: terdapat pesaing produk sejenis dan pesaing produk substitusi, jumlah konsumen berfluktuasi, biaya pengalihan ke produk lain yang relatif kecil, tidak adanya kepastian bahan baku dalam jumlah besar, ancaman populasi luwak masa mendatang dan ketersediaan air bersih yang tidak menentu. Berdasarkan hasil identifikasi lingkungan dan analisis data diketahui bahwa agroindustri kopi luwak di Kabupaten Tanjung Jabung Barat berada pada posisi kuadran 1 dan strategi yang dapat diterapkan pada posisi ini adalah mendukung kebijakan pertumbuhan agresif dengan memanfaatkan kekuatan dan peluang dalam rangka pengembangannya. Alternatif strategi pengembangan agroindustri kopi luwak di Kabupaten Tanjung Jabung Barat adalah : a) Peningkatan jumlah produksi dengan memanfaatkan ketersediaan bahan baku yang mudah diperoleh, harga bahan baku yang stabil dan melihat adanya potensi trend kopi saat ini, b) Diversifikasi dan modifikasi kemasan untuk meningkatkan daya tarik produk 
mengingat besarnya pengaruh trend kopi masa kini, c) Perluasan jangkauan pangsa pasar agar dapat bersaing dengan meningkatkan kualitas produk dan d) Bekerja sama dan menanggapi respon pemerintah dalam pengembangan usaha kopi luwak bubuk.

\section{UCAPAN TERIMA KASIH}

Pada kesempatan ini penulis menyampaikan ucapan terima kasih kepada Dinas Perindustrian, Perdagangan dan Promosi Daerah Kabupaten Tanjung Jabung Barat yang telah memfasilitasi pelaksanaan penelitian dilapangan. Ucapan terima kasih juga diucapkan kepada Kepala Bidang Industri dan Promosi Daerah Kabupaten Tanjung Jabung Barat, Kepala Bidang UMKM Kabupaten Tanjung Jabung Barat, BPTP Provinsi Jambi, Bapak Mursalin dan para pengrajin usaha kopi luwak bubuk yang telah bersedia menjadi responden dalam penelitian ini.

\section{DAFTAR PUSTAKA}

Abdul Rivai dan Darsono Prawironegoro. 2015. Manajemen Strategis (Kajian Keputusan Manajerial Bisnis Berdasar Perubahan Lingkungan Bisnis, Ekonomi, Sosial dan Politik. Mitra Wacana Media. Jakarta.

Aris Kurniawan. 2011. Meraup Untung Dari Kopi Luwak. Klik Publishing. Yogyakarta.

Clara Agustin. 2016. Trend Minum Kopi Naik. Tabloid Sinar Tani, Membangun Kemandirian Agribisnis. From: http://tabloidsinartani.com/ (Diakses 17 Februari 2016).

Dinas Perindustrian, Perdagangan, dan Promosi Daerah. 2015. Direktori Industri dan Promosi. Dinas Perindustrian, Perdagangan, dan Promosi Daerah Kabupaten Tanjung Jabung Barat.

Fatmawati. 2006. Analisis Pengembangan Agroindustri Keripik Tempe La Tahzan di Kota Jambi. Skripsi Fakultas Pertanian Universitas Jambi (Tidak Dipublikasikan).

Hunger, J. David dan Wheelen, Thomas L. 2003. Manajemen Strategis. Edisi II. Andi. Yogyakarta.

Irene K.E Wijayanti. Dyah Ethika dan Indah Widyarini. 2006. Prospek Pengembangan Agroindustri Minuman Lidah Buaya di Kabupaten Purworejo, Jawa Tengah. Jurnal Ilmiah Fakultas Pertanian Universitas Jenderal Soedirman. Purwokerto. Jawa Tengah. From : repository.upnyk.ac.id (diakses 13 Februari 2015)

Muhammad Taufik A. 2012. Manajemen Strategik Konsep dan Aplikasi. Rajawali Pers. Jakarta.

Nuning Setyowati. 2011. Analisis Usaha Dan Strategi Pengembangan Agroindustri Keripik Ketela Ungu Sebagai Produk Unggulan Di Kabupaten Karanganyar. Jurnal Ilmiah Fakultas Pertanian Universitas Sebelas Maret. Surakarta.

Rangkuti, Freddy. 2014. Teknik Membedah Kasus Bisnis Analisis SWOT. PT Gramedia Pustaka Utama. Jakarta.

Resti Ismaya. 2015. Analisis Strategi Pengembangan Agroindustri Sirup Kulit Manis di Kabupaten Kerinci. Skripsi Fakultas Pertanian Universitas Jambi (Tidak Dipublikasikan).

Siregar, M. Fikri. 2014. Analisis Nilai Tambahk Kopi Luwak Bubuk pada Agroindustri Kopi Luwak "Buana Putra" di Kabupaten Tanjung Jabung Barat.Skripsi Fakultas Pertanian Universitas Jambi (Tidak Dipublikasikan).

Sugiyono. 2010. Statistika Untuk Penelitian. Alfabeta. Bandung.

Yanti. 2006. Analisa Pengembangan Agroindustri Bihun Sari Pati di Kota Jambi. Skripsi Fakultas Pertanian Universitas Jambi (Tidak Dipublikasikan). 
Lampiran 1. Skema Matrik SWOT Agroindustri Kopi Luwak di Kabupaten Tanjung Jabung Barat

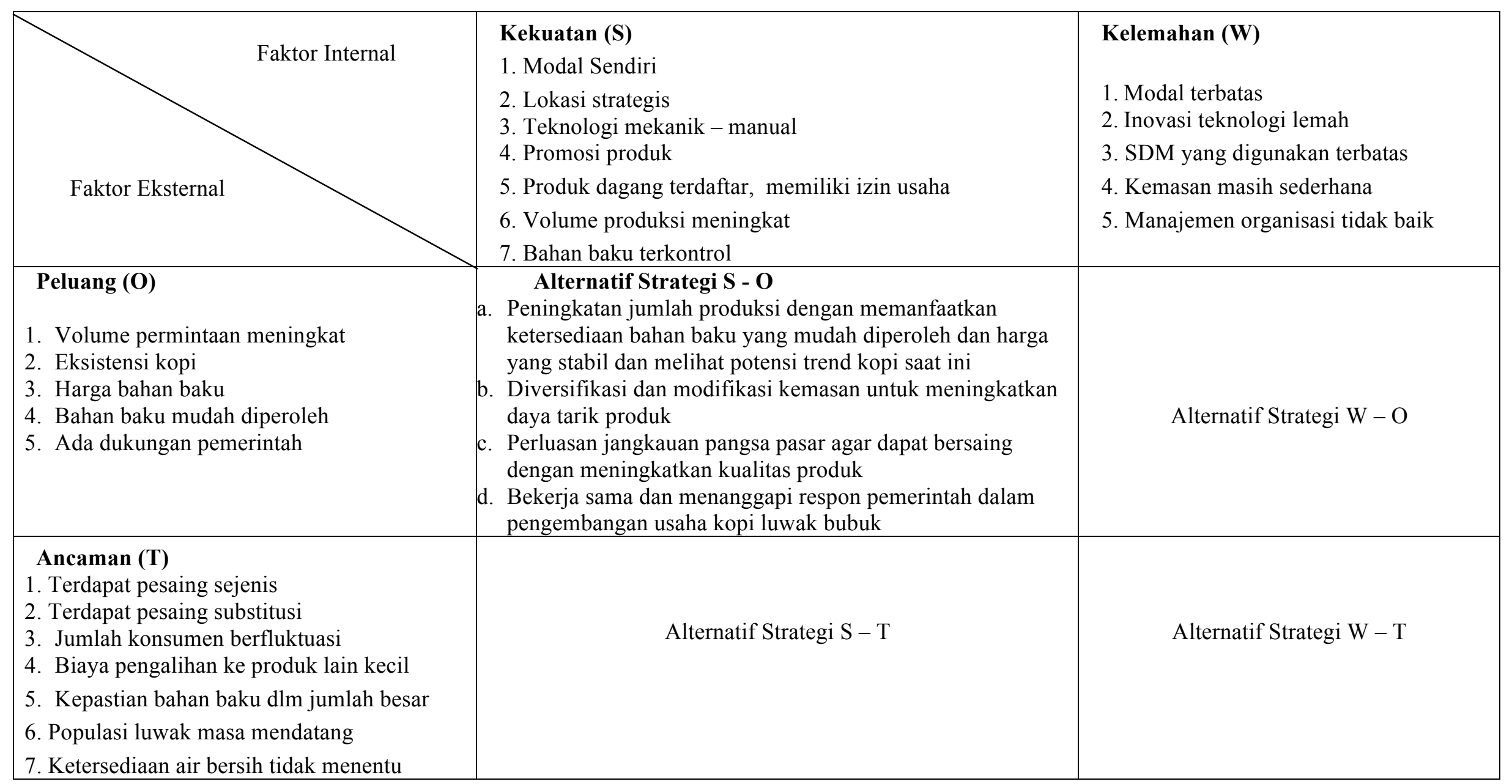


